Pobrane z czasopisma Annales H - Oeconomia http://oeconomia.annales.umcs.pl Data: 26/04/2023 02:22:39

DOI:10.17951/h.2015.59.3.71

\begin{tabular}{lcc}
\hline \multicolumn{3}{c}{ A N N A L E S } \\
UNIVERSITATIS & MARIAE CURIE-SKŁODOWSKA \\
LUBLIN - POLONIA & \\
VOL. XLIX, 3 & SECTIOH H \\
\hline
\end{tabular}

Warsaw School of Economics, Institute of International Management and Marketing

\author{
IZABELA KOWALIK \\ iza123@sgh.waw.pl
}

\title{
Marketing Activity of the International New Ventures. Results of Empirical Studies from Poland
}

Działania marketingowe przedsiębiorstw wcześnie umiędzynarodowionych. Wyniki badań empirycznych

Keywords: internationalization, marketing, international new ventures (INV).

Słowa kluczowe: internacjonalizacja, marketing, przedsiębiorstwa wcześnie umiędzynarodowione (PWU).

JEL Code: M3, F23

\section{Introduction}

During the recent two decades the "born-global" internationalization model has been extensively studied. It describes the process of rapid internationalization of organizations that, from inception, seek to derive significant competitive advantage from the use of resources and the sale of outputs in multiple countries (Oviatt et al., 1994). Such companies are called born global firms (Rennie, 1993; Knight et al., 1996; Moen et al., 2002), international new ventures (McDougall et al., 1994), born internationals (Kundu et al., 2003), or early internationalizing firms (Rialp et al., 2005) ${ }^{1}$. They are characterized by a short interval between founding and internationalization, high export share in total turnover reached within first years

1 In this article the term international new ventures (INV), developed by Oviatt and MacDougall (1994) will be used to describe the companies internationalizing according to the "born-global" model. 
of internationalization, wide geographical scope of expansion, and so-called global vision of managers.

The INVs are facing enormous challenges connected with survival and success in the foreign markets. Under circumstances of resource constraints and little managerial experience, selection of international marketing strategies is one of the most difficult tasks for them. Therefore, the INVs can exploit alternative governance structures and rely on close relationships and network partners to form international marketing channels (Gabrielsson et al., 2012). The Scandinavian authors, after studying INVs from small and open economies, specified as a type of entrepreneurial challenges they were facing, the sales and marketing challenges, connected with underinvestment in the sales and marketing function and too long implementation and planning of the marketing tasks (Luostarinen et al., 2006).

Considering the above, the study goal is to analyze the marketing activity of the INV, including the tools used and their role in creation of the competitive advantage. In particular, the study is aimed at checking how the "classical" marketing tools are applied and whether any elements of so-called "entrepreneurial marketing" (EM) concept are used by the Polish INVs. The SME companies originating in emerging markets have started international expansion only recently. Especially after the transformation of economic systems in the Central and Eastern European countries in 1990's and Poland's accession to the EU, such instant internationalization became possible. The Polish SMEs have begun internationalizing faster since 2004, and the rate of their export growth exceeded that of the LSEs twofold in 2012 (Bloomberg, 2013).

\section{Marketing activity of the INVs}

The marketing activity of the INVs has been studied to a little extent so far. The study by Luostarinen et al. (2006) has revealed that the major entrepreneurial challenges faced by these companies include sales and marketing challenges. Especially the lack of marketing planning and lack of innovative marketing techniques were the evident internal obstacles to their success. Gabrielsson (2005) examined the branding strategies of born global companies from Finland and found that during their development they change approach to branding: starting from no specified brands, up to creating single brands and then going into co-branding arrangements in later lifecycle stages. Hallback et al. (2013) basing on qualitative study of INVs found that the core elements of entrepreneurial marketing strategies in these companies were innovativeness and adaptation to local markets and clients. Moreover, greater turbulence in the environment seemed to push for more innovative marketing.

Applying the concept of entrepreneurial marketing (EM) can be a way of overcoming the challenges mentioned in relation to the INVs. EM is considerably different from corporate/traditional marketing (Martin, 2009). Beverland and Lockshin (2004) defined 
entrepreneurial marketing as effectual action or adaptation of marketing theory to the particular needs of the small business. The effectual approach is understood by these authors in line with Sarasvathy (2001) defining it as a decision-making style being in opposition to the classical, causation approach. Based on a study of American SMEs, Becherer et al. (2008) have extended the definition of EM saying that it is an organizational orientation having the underlying dimensions of proactiveness, opportunity focus, calculated risk taking, innovativeness, customer intensity, resource leveraging, and value creation. The successfully internationalizing SMEs are often characterized by flexibility in responding to customer requirements, leading to innovations in their offering and to entering new, geographically distant markets. The importance of this kind of customer focus in SME's approach to innovativeness was also confirmed by our earlier qualitative study of the Polish born global companies (Kowalik et al., 2013).

\section{Methodology}

The empirical research described in this study concerned new forms of internationalization of the Polish SMEs ${ }^{2}$ and was conducted in 2013 and 2014. The CATI method was applied, using a standardized questionnaire, containing closed and open-ended questions. We used a random stratified sample selection procedure, where representatives of manufacturing SMEs, belonging to the industrial processing branch, were interviewed. The conditions an enterprise's joining the sample had to fulfill were in line with the definition of the born global firms by Knight et al. (2004), i.e.: the interval between founding and internationalization of the SME was 3 years at the most; the export share in total turnover of at least $25 \%$ was reached within first 2 years of internationalization. In sum, we have surveyed 256 INVs in the spring of 2013 and 233 firms in autumn of $2014^{3}$. In the sample of $2014-105$ INVs and 128 gradually internationalized SME exporters (GRAD) were included for comparison purposes ${ }^{4}$.

The target respondents were persons in charge of cooperation with foreign partners. The interviews lasted ca. $25 \mathrm{~min}$., they were conducted first with directors of sales, exports, marketing, or with the firms' owners, and, if it was not possible to reach them, with sales, export, or marketing managers. The interviews included questions about the "traditional" marketing tools applied, i.e. the export product policy, pricing, distribution and promotion. In addition, questions about the companies' innovative activity and the perceived factors of competitive advantage were included.

2 The study was conducted by the Institute of International Management and Marketing as part of the statutory research of the College of World Economy, Warsaw School of Economics.

3 In 2014 a slightly modified (extended) questionnaire from 2013 was used.

4 All enterprises were established no earlier than 1990. For the GRAD subgroup, the criterion of short span from establishment to export initiation was lifted. 


\section{Results}

\subsection{Product policy}

In 2014, the studied companies were asked about the quality of their main export product compared to competitors. The mean quality level was 8.23 (st. dev. $=1.104$; $43 \%$ respondents declared the quality level equal 8 or above) $)^{5}$. There were no significant differences in product quality among sample segments (INV vs. GRAD). Furthermore, asked if on their main export market, they compete on quality, as many as 209 companies agreed with this statement ${ }^{6}$. Moreover, we have found that the majority of studied companies $(67 \%)$ introduced product or process innovations ${ }^{7}$. The innovations were introduced by significantly more GRAD companies than INV (one-way ANOVA, $\mathrm{p}=0.006$ ). The types of innovations introduced most often were: $\mathrm{a} /$ development or launch of new products, considering materials and components, $\mathrm{b} /$ considering design, c/considering technical features and $\mathrm{d} /$ more flexible, individualized approach to clients. Of the studied companies $43.8 \%$ had introduced innovations faster than their competitors.

When asked if, on their main export market, compared to their main competitor, they were better with respect to product development, $80 \%$ of companies replied positively ${ }^{8}$. However, when asked the same with respect to the number of new products launched, only $42 \%$ of studied companies replied positively (see Table 1 for the mean results concerning marketing-mix elements in comparison with competitors).

Table 1. Competitive advantage factors in the studied sample $(\mathrm{n}=233,2014)^{*}$

\begin{tabular}{|l|c|c|c|}
\hline Factors & $\begin{array}{c}\text { Mean result (scale from ,1=definitely } \\
\text { no" to 5=definitely yes") }\end{array}$ & Std. Dev. & $\begin{array}{c}\text { Std. Mean } \\
\text { error }\end{array}$ \\
\hline flexibility of pricing & 4.35 & 0.948 & 0.062 \\
\hline logistical efficiency of supply & 4.29 & 0.999 & 0.065 \\
\hline product development & 4.09 & 1.124 & 0.074 \\
\hline number of innovations & 3.61 & 1.367 & 0.090 \\
\hline marketing planning & 3.31 & 1.490 & 0.098 \\
\hline $\begin{array}{l}\text { effectiveness of advertising and other } \\
\text { forms of promotion }\end{array}$ & 3.13 & 1.579 & 0.103 \\
\hline
\end{tabular}

*Answers on 5-point Likert scales in relation to statement: "In our main export market with respect to main export product we exceed our competitors in... (e.g. flexibility of pricing)".

Source: author's elaboration

5 A scale from 1-10, where "1" means the lowest quality level accepted on the market, " 5 " - the same level as competitors, "10" - significantly higher level than competitors.

6 Statement "On the foreign markets we compete mainly on quality" (answers on 5-point Likert scale, from "definitely no" to "definitely yes").

7 Questions "Does the company introduce innovations in form of new products, new processes or technologies?” and „Please name examples of such innovations”.

8 An aggregate of the positive answers on 5-point Likert scale. 
Similar results regarding the product policy were obtained in 2013. The vast majority of companies admitted their main export product's quality was high compared to competitors ( $82 \%$ of studied firms). Two-thirds of the sample admitted they had introduced innovations and new technologies. Among them $72(47 \%)$ mentioned product innovations (NPD, design, functionality, packaging); 65 (42\%) of the innovating companies studied in 2013 were faster than competitors to introduce innovations to the market.

\subsection{Distribution}

A remarkable number of companies in the 2014 sample (76\%) admitted they exceeded their competitors with respect to efficiency of supply (see also Table 1) . A similar result was obtained for the same question in the 2013 study, when $65 \%$ of companies admitted they exceeded their competitors with respect to efficiency of supply. However, when asked an open question about the factors which make the company successfully win in competition in foreign markets only 44 companies mentioned timeliness and efficiency of their activity and 36 mentioned logistics as such factors (see Table 3).

When asked if any innovations were introduced in their distribution, only $13 \%$ of firms in the 2014 sample agreed (among them more INVs than GRADs). As examples of these innovations, they mentioned "searching for new intermediaries" $(n=20)$; "acquiring new vehicles" $(n=9)$; "opening new branches" $(n=7)$; "using order monitoring systems" $(\mathrm{n}=5)$.

\subsection{Pricing}

When asked about the pricing level applied on export markets, $63 \%$ of the respondents in the 2014 sample admitted they used similar (medium) prices as the competitors. The INVs and GRADs applied similar pricing levels (no significant differences were revealed in ANOVA).

When asked if on their main export market, compared to their main competitor, the companies were better with respect to pricing flexibility, $80 \%$ of companies studied in 2014 agreed $^{10}$. The application of competitive, flexible pricing wasn't significantly differentiated among the segments of the 2014 sample. However, when asked an open question about the factors which make the company successfully win in competition in foreign markets, only 57 companies mentioned competitive pricing (see Table 3). In 2013 also 64\% of studied INV admitted they applied medium prices.

\footnotetext{
${ }^{9}$ There was no significant difference between the segments of INV and GRAD companies with respect to this competitiveness factor.

${ }^{10}$ Aggregate No. of positive answers, see also Table 1.
} 


\subsection{Promotion and branding}

In general $48 \%$ of enterprises studied in 2014 admitted they actively promoted their products on the foreign markets ${ }^{11}$. Significantly better results were obtained by the INVs, compared to the GRADs (one-way ANOVA, $\mathrm{p}=0.03$, Table 2).

Table 2. One-way analysis of variance of the answers to question "We actively promote our products on the foreign markets"

\begin{tabular}{|l|c|c|c|c|c|}
\hline & Sum of squares & Df & Mean square & F & Significance \\
\hline Between groups & 30.458 & 3 & 10.153 & 4.702 & 0.003 \\
\hline Within groups & 492.330 & 228 & 2.159 & & \\
\hline Total & 522.789 & 231 & & & \\
\hline
\end{tabular}

Tukey's HSD test

\begin{tabular}{|l|l|c|c|c|}
\hline \multirow{4}{*}{$\begin{array}{l}\text { (I) INVs immediately } \\
\text { export-oriented } * *\end{array}$} & $\begin{array}{l}\text { (J) INVs or GRADs/ immediately or not } \sim \\
\text { export-oriented: }\end{array}$ & $\begin{array}{c}\text { Means } \\
\text { difference (I-J) }\end{array}$ & Std.error & Significance \\
\cline { 2 - 5 } & GRADs immediately export-oriented & 0.688 & 0.301 & 0.105 \\
\cline { 2 - 5 } & INVs not immediately export-oriented & $1.059^{*}$ & 0.318 & 0.006 \\
\cline { 2 - 5 } & GRADs not immediately export-oriented & $0.621^{*}$ & 0.229 & 0.036 \\
\hline
\end{tabular}
$*$ Means difference significant at $0.05 . * *$ Immediately export oriented companies reached a $25 \%$ share of export in total
revenues within 1 year of export initiation.

Source: author's own elaboration

The most frequently mentioned tools used by the "active promoters" were conferences and fairs, internet webpages, direct contacts with clients. Other, less popular forms, were mass media promotion and contacts with Polish diplomatic posts.

The companies studied in 2014 were also asked if they used any innovative advertising and promotion techniques. Among 101 who did, examples of such tools were mainly: webpages, fairs and exhibitions, advertising during events. The GRADs used innovative forms of promotion more often than INVs (ANOVA, $p=0.04$ ).

Similarly, in our 2013 sample, $58 \%$ of companies admitted they engaged actively in promotion. Among them, the companies whose export share in total revenues was the highest (from $80 \%$ up) engaged in promotion less actively than those with medium share of exports in their revenues (one-way ANOVA, $\mathrm{p}=0.008$ ). When asked about the innovative marketing techniques used, only $21 \%$ of INVs admitted they applied them. Among the examples they mentioned advertising, direct marketing and sales promotion. When asked if the promotional efforts contributed significantly to their competitive advantage, only 63 (25\%) companies admitted they did.

In $2014,55 \%$ of the companies studied admitted they used their own brands on their products, among them almost equally INVs and GRADs (in the study of 2013, $46 \%$ INVs admitted so).

\footnotetext{
${ }^{11}$ Aggregate No. of positive answers on 5-point Likert scales.
} 


\subsection{Marketing planning and success factors}

When asked if the studied companies were better with respect to marketing planning, compared to their main competitor, only 21\% in 2014 agreed. In 2013 there were $18 \%$ of such companies, and this activity did not change with the change of export share in total revenues. Moreover, in 2014 only one-third of the studied companies admitted they had conducted any research concerning the chances for success before entering foreign markets.

At the end of the study in an open question, several of the analyzed marketing-mix tools were mentioned spontaneously as factors making the companies successfully compete in the foreign markets ${ }^{12}$. They were: product quality, coupled with broadening of the product offer and innovativeness; logistics and timeliness of actions; flexibility to customer requirements and competitive pricing. The frequencies of answers are shown in Table 3.

Table 3. Success factors listed by the studied companies $(2014, \mathrm{n}=233)$

\begin{tabular}{|l|c|c|c|c|c|c|c|}
\hline $\begin{array}{c}\text { Company } \\
\text { type }\end{array}$ & $\begin{array}{c}\text { Systematic } \\
\text { broadening } \\
\text { of product } \\
\text { range }\end{array}$ & $\begin{array}{c}\text { Modern, } \\
\text { innovative } \\
\text { products }\end{array}$ & $\begin{array}{c}\text { High } \\
\text { quality } \\
\text { products }\end{array}$ & $\begin{array}{c}\text { Timeliness } \\
\text { and } \\
\text { effectiveness } \\
\text { of actions }\end{array}$ & Logistics & $\begin{array}{c}\text { Competitive } \\
\text { Pricing }\end{array}$ & $\begin{array}{c}\text { Flexibility } \\
\text { to customer } \\
\text { requirements }\end{array}$ \\
\hline INV & 12 & 17 & 55 & 23 & 11 & 30 & 31 \\
\hline GRAD & 18 & 9 & 64 & 21 & 25 & 27 & 32 \\
\hline Total & 30 & 21 & 119 & 44 & 36 & 57 & 63 \\
\hline
\end{tabular}

Source: author's own elaboration

In 2013, similar as in the results shown above, 93\% companies admitted they competed on the quality of offering and $46 \%$ - on low pricing ${ }^{13}$.

\section{Discussion and conclusions}

In conclusion, common results related to specific marketing tools used by the INV companies, obtained from both samples are presented (see Table 4).

The "marketing challenges" relating to INVs, mentioned by the Scandinavian authors are evident also in the analyzed Polish companies, although not only INVs, but also GRADs. They relate especially to the promotion sphere and marketing planning. Few studied companies engage in active promotion (although more INV than GRAD) and few innovative tools are used. On the other hand, the presented results

\footnotetext{
12 "Please point to the factors (resources, capabilities) which make your company compete successfully in the foreign markets".

${ }^{13}$ Answers on 5-point Likert scales to the statements "In the foreign markets we compete mainly with low pricing (high quality)".
} 
Pobrane z czasopisma Annales H - Oeconomia http://oeconomia.annales.umcs.pl

Data: 26/04/2023 02:22:39

IZABELA KOWALIK

Table 4. Summary of results concerning both 2013 and 2014 samples

\begin{tabular}{|l|l|}
\hline Tool used & Key results \\
\hline Product & $\begin{array}{l}\text { - very high average quality of offering compared to competitors, main success factor } \\
- \text { competitive advantage considering product development process and number of innovations } \\
- \text { innovations in product design and in technical features mainly in INV companies }\end{array}$ \\
\hline Price & $\begin{array}{l}- \text { one of the most important success factors } \\
- \text { competitive advantage considering pricing flexibility } \\
- \text { medium level of prices, compared to competitors }\end{array}$ \\
\hline Place & $\begin{array}{l}\text { - high effectiveness of distribution in both samples } \\
- \text { low innovativeness considering distribution tools } \\
- \text { distribution not perceived as the main competitiveness factor }\end{array}$ \\
\hline Promotion & $\begin{array}{l}- \text { c.a. half of the INVs actively promote their products on foreign markets } \\
- \text { low innovativeness of promotional tools }\end{array}$ \\
& $\begin{array}{l}\text { - active promotional efforts and branding policy are more common in INVs with low-to medium } \\
\text { export shares in total revenues }\end{array}$ \\
\hline $\begin{array}{l}\text { Marketing } \\
\text { planning }\end{array}$ & $\begin{array}{l}- \text { low importance of marketing planning } \\
- \text { low importance of formal intelligence generation (2014) }\end{array}$ \\
\hline
\end{tabular}

Source: author's own elaboration

reveal high importance of product policy, together with flexibility in responding to customer requirements (also considering distribution and pricing). These results are in line with studies concerning the entrepreneurial marketing concept. The majority of EM definitions recognize innovativeness and customer focus as the crucial elements of entrepreneurial activity (see e.g. Gilmore, 2011; Becherer et al. 2008). The application of EM strategies is accompanied with the use of so-called "new 4 Ps", i.e. the new marketing tools (Martin, 2009; Gilmore, 2011), concentrated on new product development, direct communication with customers, the use of networks, and putting an emphasis on relationship building in the foreign markets.

Furthermore, the strategic tools, such as marketing planning and intelligence gathering, are seldom used by the studied Polish INVs, which may testify to an "effectuation" approach to decision making. This approach, characteristic of SMEs, had been described as useful in analyzing the activity of the born-global companies abroad (Andersson, 2011).

Summing up, the results indicate that the EM concept could be applied in the marketing activity of the Polish INVs. However, considering this study's exploratory character, further analysis to support this thesis is required. As part of future research, the particular dimensions of EM, already tested in other countries should be analyzed (see e.g. Becherer et al. 2008; Hacioglu et al., 2012). Moreover, the presented results have some limitations. They are based on respondents' declarations and subjective opinions concerning company performance. In further research, they could be confronted with some objective indicators (e.g. company marketing and financial results) and supplemented with data concerning the characteristics of marketing environment of the studied companies. 


\section{Summary}

The marketing activity of the Polish-based international new ventures is particularly focused on the product policy and innovativeness. The remaining "classical" tools, especially the promotional ones are used much more rarely, and not innovatively. Furthermore, an individualized, flexible approach to clients is emphasized as an important competitive tool. These and other results, obtained on the basis of two randomly selected samples of the Polish INV suggest that they apply elements of so-called entrepreneurial marketing concept, which has been described in the foreign literature in relation to SMEs and born-global companies. This concept can be useful in overcoming the "managerial challenges" to INV functioning, but its particular dimensions require further analysis.

\section{References}

1. Andersson S., International entrepreneurship, born globals and the theory of effectuation, Journal of Small Business and Enterprise Development, Bingley: Emerald Group, 2011, Vol. 18, No. 3.

2. Becherer R.C., Haynes P.J., Helms M.M., An exploratory investigation of entrepreneurial marketing in SMEs: The influence of the owner/operator, Journal of Business and Entrepreneurship, London: Taylor\&Francis, 2008, Vol. 20, No. 2.

3. Beverland M., Lockshin L.S., Crafting a competitive advantage: Tempering entrepreneurial action with positioning-based values, Qualitative Market Research, Bingley: Emerald Group, 2004, Vol. 7, No. 3.

4. Gabrielsson M., Branding strategies of born globals, Journal of International Entrepreneurship, New York: Springer Science and New Media, 2005, Vol. 3, No. 3.

5. Gabrielsson M, Kirpalani V.H.M. eds., Handbook of Research on Born Globals, New York: Edward Elgar Publishing, 2012. http://dx.doi.org/10.4337/9780857938046

6. Gilmore A., Entrepreneurial and SME marketing, Journal of Research in Marketing and Entrepreneurship, Bingley: Emerald Group, 2011, Vol. 13, No. 2.

7. Hacioglu G., Erenc S.S., Sule Erenc M., Celikkand H., The effect of entrepreneurial marketing on firm's innovative performance in Turkish SMEs, Procedia - Social and Behavioral Sciences, 2012, Vol. 58.

8. Hallback J., Gabrielsson P., Entrepreneurial marketing strategies during the growth of international new ventures originating in small and open economies, International Business Review, Paris: Elsevier, 2013, Vol. 22.

9. Knight G.A., Cavusgil S.T., The born global firm: A challenge to traditional internationalization theory, Advances in International Marketing, Bingley: Emerald Group, 1996, Vol. 8.

10. Knight G.A., Madsen T.K., Servais P., An inquiry into born global firms in Europe and the USA, International Marketing Review, Bingley: Emerald Group, 2004, Vol. 21, No. 6.

11. Kowalik I., Baranowska-Prokop E., Determinanty powstawania i motywy ekspansji polskich przedsiębiorstw wcześnie umiędzynarodowionych, Gospodarka Narodowa, Warszawa: Szkoła Główna Handlowa, 2013, Vol. 4.

12. Kundu S.K., Katz J.A., Born-internationals SME: BI-level impacts on resources and intentions, Small Business Economics, New York: Springer Science and Economics, 2003, Vol. 20. 
13. Luostarinen R., Gabrielsson M., Globalization and Marketing Strategies of Born Globals in SMOPECs, Thunderbird International Business Review, New Jersey: Wiley Periodicals, 2006, Vol. 48, No. 6.

14. Mate i średnie firmy motorem polskiego eksportu, "Bloomberg Businessweek Polska", 2013/21.

15. Martin D.M., The entrepreneurial marketing mix, Qualitative Market Research, Bingley: Emerald Group, 2009, Vol.12, No. 4.

16. McDougall P.P., Oviatt B.M., International Entrepreneurship: the intersection of two research paths, Academy of Management Journal, Briarcliff Manor: Academy of Management, 2000, Vol. 43, No. 5. http://dx.doi.org/10.2307/1556418

17. Moen Ø., Servais P., Born Global or Gradual Global? Examining the Export Behavior of Small and Medium-Sized Enterprises, Journal of International Marketing, Chicago: American Marketing Association, 2002, Vol. 10, No. 3.

18. Oviatt B.M., McDougall P.P., Toward a Theory of International New Ventures, Journal of International Business Studies, London: Palgrave Macmillan, 1994, Vol. 25.

19. Rennie M.W., Global competitiveness: Born global, McKinsey Quarterly, New York: McKinsey \& Co, 1993, Vol. 4.

20. Rialp A., Rialp J., Knight G.A., The phenomenon of early internationalizing firms: what do we know after a decade (1993-2003) of scientific inquiry? International Business Review, Paris: Elsevier, 2005, Vol. 14, No. 2.

21. Sarasvathy S., Causation and effectuation: Toward a theoretical shift from economic inevitability to entrepreneurial contingency, Academy of Management Review, Briarcliff Manor: Academy of Management, 2001, Vol. 26, No. 2.

\section{Marketing Activity of the International New Ventures. Results of Empirical Studies from Poland}

Abstract. According to the literature, so-called managerial challenges are among the important barriers in the process of SMEs internationalization. Thus, the study is aimed at analyzing the marketing activity of the Polish SME-exporters, based on two quantitative studies of randomly selected Polish companies from the industrial processing sector. The studied topics include: marketing tools applied, new product development policy, competitive advantage factors perceived by the respondents. As the results show, the so-called international new ventures apply elements of entrepreneurial marketing concept on the foreign markets. These include: emphasis on product innovativeness, flexibility towards customer requirements and lack of long-term marketing planning which complies with studies conducted abroad.

\section{Działania marketingowe przedsiębiorstw wcześnie umiędzynarodowionych. Wyniki badań empirycznych}

Abstrakt. Zgodnie z literaturą tzw. wyzwania menedżerskie należą do najważniejszych barier w procesie internacjonalizacji małych i średnich firm. Celem artykułu jest zatem analiza działań marketingowych polskich MSP-eksporterów w oparciu na badaniach ilościowych przeprowadzonych na dwóch losowo dobranych próbach. Analiza dotyczy m.in. stosowanych narzędzi marketingowych, polityki rozwoju nowych produktów i nadawania marki. Wyniki sugerują, że przedsiębiorstwa wcześnie umiędzynarodowione (tzw. international new ventures) prowadzą działania charakterystyczne dla koncepcji marketingu przedsięborców (tzw. entrepreneurial marketing), związanej z innowacyjnością, elastycznością w stosunku do wymagań nabywców i brakiem długoterminowego planowania, co jest zgodne z analogicznymi badaniami zagranicznymi. 